\title{
Bioprospecting for extracellular enzymes from endophytic bacteria isolated from Vigna radiata and Cajanus cajan
}

\author{
Namita Bhutani, Rajat Maheshwari, Pradeep Kumar, Rakhi Dahiya, Pooja Suneja* \\ Plant-Microbe Interaction Laboratory, Department of Microbiology, Maharshi Dayanand University, Rohtak, Haryana, India.
}

\begin{tabular}{|c|c|}
\hline $\begin{array}{l}\text { Article history: } \\
\text { Received on: January } 08,2021 \\
\text { Accepted on: February } 05,2021 \\
\text { Available online: May } 10,2021\end{array}$ & $\begin{array}{l}\text { Endophytes are known to improve plant growth using a multitude of mechanisms. Bacteria use a variety of } \\
\text { mechanisms to penetrate and reside in a host. Producing hydrolytic enzymes is one of these mechanisms which } \\
\text { hydrolyses the cell wall components of plant cells helping bacteria to enter through root hairs and lateral roots. The } \\
\text { present study focused on the production of hydrolytic enzyme by endophytic bacteria isolated from Vigna radiata and }\end{array}$ \\
\hline $\begin{array}{l}\text { Key words: } \\
\text { Amylase, } \\
\text { Cajanus cajan, } \\
\text { Cellulase, } \\
\text { Pectinase, } \\
\text { Protease, } \\
\text { Vigna radiata }\end{array}$ & $\begin{array}{l}\text { Cajanus cajan. Out of forty seven endophytic bacteria, nine isolates, namely, MJiR8, MJiN16, MJiN13, MJhN14, } \\
\text { ARR4, MBR9, MHN3, MBN2, and MHN12 were found to produce all the four enzymes, namely, amylase, cellulase, } \\
\text { protease, and pectinase. Five isolates ARR4, MBR9, MHN3, MJiN13, and MHN12 showed distinct restriction } \\
\text { pattern on the basis of ARDRA profiling and further identified using 16S rDNA sequencing. The results revealed } \\
\text { their identity toward the different species of Bacillus or Bacillus derived genera, that is, ARR4 (Bacillus megaterium } \\
\text { NAP8), MBR9 (Bacillus subtilis NMP1), MHN3 (Bacillus cereus NMP2), MJiN3 (Bacillus panacihumi NMP3), } \\
\text { and MHN12 (Bacillus licheniformis MHN12). The isolates also possessed different plant growth promoting (PGP) } \\
\text { features and significantly enhanced all plant growth parameters except nodulation. These highly efficient strains with } \\
\text { multiple enzyme production and PGP features can be harnessed to facilitate the close association between host plants } \\
\text { and PGP bacteria providing better yield and reduced application of agro-chemicals. }\end{array}$ \\
\hline
\end{tabular}

\section{INTRODUCTION}

Endophytic bacteria, omnipresent in every plant species known, have been isolated from all plant parts, namely, leaves, stems, flowers, roots, and seeds [1]. These endophytes are sheltered inside the plant tissue from environmental stresses and microbial competition and, in turn, improve the health of host plant directly by procuring nutrients, indirectly by defeating soil borne pathogens or ameliorating the ill effects caused by environment [2-5]. The endophytic bacteria enter into plants interior by several mechanisms, cracks or wounds in primary and lateral roots being the most common mode, as the plant metabolites leakage through these sites attracts the bacteria [6]. Bacteria also enter through the root hairs and lateral roots by producing hydrolytic enzymes such as cellulases, pectinases, proteases, and lipases and hydrolyze the cell wall components of epidermis, hypodermis, and cortical cells $[7,8]$. Plant growth promoting (PGP) endophytic bacteria also synthesize other enzymes such as amylases, esterases, chitinases, and $\beta-1,3$ glucanases [9]. There is always a strong interest in microbial enzymes because of commercial application in numerous fields such as textile industry, food processing, agriculture research, and pharmaceuticals.

*Corresponding Author:

Dr. Pooja Suneja, Department of Microbiology, Maharshi Dayanand

University, Rohtak - 124 001, Haryana, India.

E-mail:poojapavit@gmail.com
Despite being playing a role in PGP, these endophytes can also be explored as a source of microbial enzymes.

Bacterial cellulases are capable of catalyzing cellulosic biomass, the principal component of all existing plant cell walls and the most abundantly present biopolymer in nature [10]. Thus, the enzyme cellulase has many useful applications in the paper industry, bioethanol generation, textile industries, detergent industry, and animal feed production [11]. Amylase hydrolyses the starch by catalyzing $\alpha-1,4$ glycosidic linkage, and world widely used commercially for preparation of sugar syrups, starch liquefaction, paper, food, pharmaceuticals industries, etc. [12]. Production of peptide digesting microbial proteases gained attention due to their broad use in the detergent, food, chemical, pharmaceutical, and leather processing industries [13]. Pectinases are the enzymes that cause breakdown of pectin by depolymerizing the bonds. Many organisms produce pectinolytic enzymes but bacterial pectinases are predominately most advantageous over others. Therefore, these enzymes have immense application in juice and food industries, paper and pulp industries, decomposition, recycling industries, etc. [14].

Endophytes residing in leguminous crops fix atmospheric nitrogen, control soil-borne pathogens, produce useful metabolites such as auxins, siderophores, hydrogen cyanide ( $\mathrm{HCN})$, and play an important role in PGP [15-17]. Exploration of endophytic bacteria to produce number of exocellular enzymes allowing them to enter the host interior and their effect on PGP will be a great opportunity in industrial and 
agriculture field. Therefore, in the present study endophytic bacteria from roots and nodules of leguminous crops were screened for enzymes of industrial importance, namely, amylase, cellulase, protease, and pectinase. Furthermore, these endophytic bacterial strains with multiple enzyme activities were also investigated for the PGP potential.

\section{MATERIALS AND METHODS}

\subsection{Microbial Cultures}

A total of forty seven endophytic bacteria isolated from mungbean (Vigna radiata) and pigeon pea (Cajanus cajan) plants grown in different districts of Haryana (India) were obtained from our laboratory. Out of total, twenty isolates from roots and twenty seven isolates from nodules were used in the present study. The cultures were maintained on tryptone soy agar slants at $4{ }^{\circ} \mathrm{C}$ and preserved in $50 \%$ glycerol at $-20^{\circ} \mathrm{C}$.

The study was carried out during the period of February 2019 to February 2020, in the Department of Microbiology of Maharshi Dayanand University, Rohtak, Haryana, India.

\subsection{Exoenzyme Production by Endophytic Isolates}

Amylase, cellulase, protease, and pectinase production were evaluated using specific indicator media supplemented with $1 \%$ starch, $0.5 \%$ carboxymethyl cellulose (CMC), $1 \%$ casein and $0.5 \%$ pectin, respectively. After an incubation of $48 \mathrm{~h}$, enzymatic index (EI) was measured and expressed as Hankin and Anagnostakis [18].

$$
\text { Enzymatic index }=\frac{\text { Colony diameter }(\mathrm{cm})+\text { Halozone diameter }(\mathrm{cm})}{\text { Colony diameter }(\mathrm{cm})}
$$

For amylase production, Gram's iodine was flooded over the starch medium and perceived for appearance of colorless zone around the growth [19]. For cellulase production, the medium was flooded with Congo red solution $(0.5 \%)$ for $15 \mathrm{~min}$, discarded and then washed with sodium chloride $(\mathrm{NaCl})$ solution $(1 \mathrm{M})$. The formation of clear zone around the growth indicated the cellulase production [20]. Protease activity was determined by the presence of clear halo around the colonies on casein agar plates. For pectinase activity, surface of medium was flooded with $2 \%$ hexadecyl trimethyl ammonium bromide for $30 \mathrm{~min}$, allowing the appearance of zone around bacterial growth [21].

\subsection{Enzymatic Assay}

The isolates were grown in nutrient broth supplemented with soluble starch $(1 \%), \mathrm{CMC}(1 \%)$, casein $(1 \%)$, and polygalacturonic acid $(0.5 \%)$ for amylase, cellulase, protease, and pectinase activity, respectively. One unit of enzyme activity is defined as the amount of enzyme required to catalyze $1 \mu \mathrm{mol}$ of the substrate in $1 \mathrm{~min}$.

\subsection{Calculation of Enzyme Activity}

Enzymatic activity $(\mathrm{IU} / \mathrm{ml})=\left(\begin{array}{l}\text { Amount of substrate consumed }(\mu \mathrm{mol}) \\ \times \text { dilution factor } \times 1000 \\ \text { Molecular weight of glucose }(\mu \mathrm{mol}) \\ \times \text { time } \mathrm{x} \text { enzyme reaction volume }(\mathrm{ml})\end{array}\right)$

\subsubsection{Amylase activity}

The crude enzyme was obtained by centrifuging the bacterial culture $(10,000 \mathrm{rpm} \times 15 \mathrm{~min})$ and to $0.5 \mathrm{ml}$ of culture supernatant, $0.5 \mathrm{ml}$ of freshly prepared starch solution was added. After an incubation of $5 \mathrm{~min}$ at room temperature, amylolytic activity was stopped by adding $1 \mathrm{ml}$ of 3,5-dinitrosalicylic acid (DNS) solution. The solution was then heated in boiling water bath for $5 \mathrm{~min}$ and allowed to cool down. The volume was made up to $10 \mathrm{ml}$ by adding distilled water and absorbance was measured at $540 \mathrm{~nm}$. The absorbance values were transformed into micromoles of reducing sugar produced during the reaction using standard curve of maltose.

\subsubsection{Cellulase activity}

To the $1 \mathrm{ml}$ of culture supernatant, added $1 \mathrm{ml}$ of $1 \% \mathrm{CMC}$ in $0.1 \mathrm{M}$ sodium acetate buffer. Incubated the solution for $5 \mathrm{~min}$ at $65^{\circ} \mathrm{C}$ for cellulytic activity and then the reaction was stopped by adding $2.5 \mathrm{ml}$ of DNS. The mixture was heated at boiling water bath for 5 min and cooled down thereafter. Concentration of reducing sugar produced was detected by comparing optical densities $(540 \mathrm{~nm})$ with the standard curve of glucose.

\subsubsection{Protease activity}

The bacterial broth was centrifuged at $5000 \mathrm{rpm}$ for $6 \mathrm{~min}$ and $150 \mu \mathrm{l}$ of supernatant was mixed with $300 \mu \mathrm{l}$ of $1 \%$ casein dissolved in $20 \mathrm{mM}$ Tris- $\mathrm{HCl}(\mathrm{pH}=7.4)$. For protease activity, incubated the mixture at $30 \pm 2{ }^{\circ} \mathrm{C}$ for $30 \mathrm{~min}$. To stop the reaction, $450 \mu \mathrm{l}$ of $10 \%$ tri-chloroacetate $(\mathrm{w} / \mathrm{v})$ was added to make the final concentration of $5 \%(\mathrm{w} / \mathrm{v})$ and incubated for $1 \mathrm{~h}$ at room temperature. The mixture was again centrifuged at 12,000 rpm for $5 \mathrm{~min}$ and absorbance measured at $280 \mathrm{~nm}$ [22]. Protease concentration was determined by comparing the absorbance value with tyrosine standard curve.

\subsubsection{Pectinase activity}

For pectinase activity, $0.5 \mathrm{ml}$ of supernatant $(6000 \mathrm{rpm}$ for $10 \mathrm{~min})$ was mixed with equal volume $(0.5 \mathrm{ml})$ of $1 \%$ pectin solution prepared in $0.05 \mathrm{M}$ citrate buffer $(\mathrm{pH}=5)$. It was then incubated for $30 \mathrm{~min}$ at $50^{\circ} \mathrm{C}$ for reaction to take place. The reaction was stopped with $1.5 \mathrm{ml}$ of DNS and kept in boiling water bath for $5 \mathrm{~min}$ [19]. Absorbance was measured at $540 \mathrm{~nm}$ and compared with glucose standard curve.

For control, the crude enzyme was replaced by uninoculated media. All the results were analyzed statistically with at least three replicates of each sample and given as mean \pm SEM (Standard error of mean).

\subsection{Molecular Identification of Isolates}

\subsubsection{Genomic DNA extraction and 16S rDNA amplification}

Molecularidentification was conducted using 16SrDNAgenesequencing. Modified CTAB method was used to extract genomic DNA of pure cultures [4]. Amplification of 16S rDNA gene was achieved thermocycler (BioRad, USA) using 8F (5'AGAGTTTGATCCTGGCTCAG 3') as forward primer and 1541R (3'AAGGAGGTGATCCAGCC 5') as reverse primer [23,24]. The reaction mixture of $30 \mu \mathrm{l}$ containing 0.25 $\mu \mathrm{M}$ of each primers, $1.5 \mathrm{mM} \mathrm{MgCl}{ }_{2}, 0.2 \mathrm{mM}$ of each dNTP, $1 \mathrm{X}$ Taq polymerase buffer, $1 \mathrm{U}$ of Taq polymerase (Promega, USA), and $50 \mathrm{ng}$ DNA template was subjected to initial denaturation of for $3 \mathrm{~min}$ at $94^{\circ} \mathrm{C}$, followed by 30 cycles of $3.5 \mathrm{~min}$ each including $45 \mathrm{sec}$ at $94^{\circ} \mathrm{C}, 45 \mathrm{sec}$ at $58^{\circ} \mathrm{C}, 2 \mathrm{~min}$ at $72^{\circ} \mathrm{C}$ and subsequent final extension for $7 \mathrm{~min}$ at $72^{\circ} \mathrm{C}$. The amplification was confirmed by obtaining high reproducibility of the band patterns by agarose $(1.2 \% \mathrm{w} / \mathrm{v})$ gel electrophoresis (GeNei Pvt. Ltd., Bengaluru, India) at $60 \mathrm{~V}$ for $40 \mathrm{~min}$ and observed under gel documentation system (Azure Biosystems, Dublin, CA 94568 USA).

\subsubsection{ARDRA (amplified ribosomal DNA restriction analysis)}

Restriction endonuclease MspI, HinfI, and HaeIII were used for restriction digestion of amplified 16S rDNA product. For this digestion, $5 \mu \mathrm{L}$ of amplified 16S rDNA product was treated with 5 units of restriction 
enzyme and held at constant temperature of $37^{\circ} \mathrm{C}$ for $4 \mathrm{~h}$ in dry water bath. The digested product was resolved on $1.5 \%$ agarose gel. Two-dimensional binary matrices were prepared from the polymorphic patterns of restriction digestion profiles and combined for cluster analysis. Binary matrices were constructed with the help of SimQual coefficient and further analyzed by UPGMA cluster analysis using biostatistical analysis program NTSYSPC program 2.1 of Exeter Software's USA [25].

\subsection{3. $16 S$ rRNA gene sequencing}

The isolates were identified by 16s rRNA gene sequencing (AgriGenome Labs Pvt. Ltd., Kochi, India). The obtained sequences were compared with genome data available at National Center for Biotechnology Information (NCBI) Basic Local Alignment Search Tool (BLAST) server. Similar sequences redeemed and multiple sequence alignment was performed. The phylogenetic tree was constructed by Mega X software using neighbor joining method with 1000 bootstrap data sets [26].

\subsection{Plant growth promoting traits}

The isolates were also screened for PGP properties, namely, organic acid, ammonia, HCN, IAA, siderophore production, and P- solubilization. Ammonia and organic acid production was tested by adding Nessler's reagent and methyl red to 5 days old culture grown in peptone water and MRVP broth, respectively [27]. HCN production was detected using Lorck's method [28]. For siderophore production and phosphate solubilization, inoculum was spotted on CAS (Chrome azurol S) agar [29] and Pikovskaya's agar [30] plates, respectively. Phytohormone IAA production was estimated by colorimetric assay using Salkowski's method [31].

\subsection{Pot Experiment}

The ability of these endophytic isolates to promote plant growth was also assessed under pot culture conditions using $V$. radiata as test host. Seed bacterization was done by incubating the seeds overnight with endophytic bacterial isolates and sown in a set of five seeds per pot. Three pots of each isolate were used to minimize the data error. After germination, three plants in each pot were maintained by uprooting the extra plantlets and irrigated with Slogger's solution every day or as and when required. Plants were uprooted after 60 days of growth and observed for various parameters, namely, number of nodules, root and shoot length, fresh and dry weight of roots and shoots [32].

\section{RESULTS AND DISCUSSION}

\subsection{Screening of Endophytic Bacteria for Exoenzyme Production}

Endophytic bacteria are common inhabitants of every plant tissue and the recent studies on these bacteria mainly focused on improvement of economically important crops, biocontrol, and sustainable agriculture. Hydrolytic enzymes are secreted extracellularly by endophytic bacteria and help the plants to setup systemic resistance against attack by pathogens $[33,34]$. The endophytic bacteria obtained from our laboratory were screened for the presence of active exoenzymes, namely, amylase, cellulase, protease, and pectinase [Figure 1]. The enzymatic index of all the isolates was assessed and observed that all of them possessed ability to produce one or more exoenzyme except isolates MJiN3, MHN19 and MHN20 [Table 1]. Among them, nine isolates, that is, MJiR8, MJiN16, MJhN14, ARR4, MBR9, MHN3, MJiN13, MBN2, and MHN12 produced all the four enzymes while others produced combination of two or three enzymes [Figure 2]. Enzymatic index is the practical and rapid tool for estimating enzyme production by bacteria. Enzymatic index more than 1.0 indicates the enzyme secretion by isolates [35].

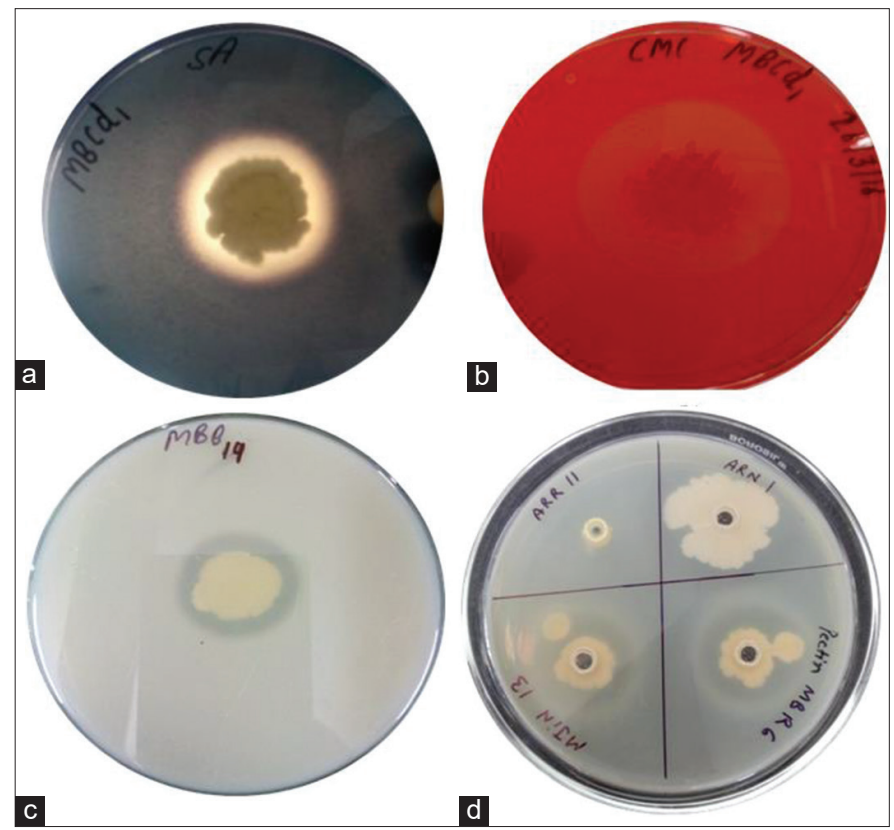

Figure 1: Zone of hydrolysis shown by endophytic bacterial isolates on nutrient agar plates supplemented with (a) $1 \%$ starch; (b) $0.5 \%$ carboxymethyl cellulose; (c) $1 \%$ casein; and (d) $0.5 \%$ pectin.

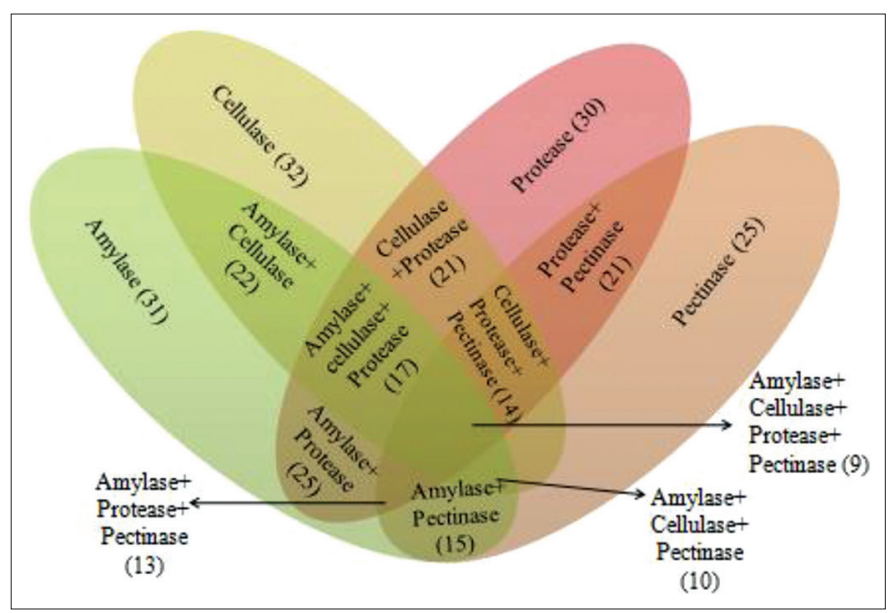

Figure 2: Venn diagram showing integrative exoenzyme production by bacterial isolates.

In the present study, the enzyme producing isolates produced $\mathrm{EI} \geq 1.0$ for at least one of the four evaluated enzymes, showing their potential for industrial applications. Highest amylase production was shown by isolate MJiR8 with EI of 2.1; cellulase and protease production by MBR9 with Enzymatic index of 2.79 and 2.38, respectively; pectinase production by isolate MJiN13 with EI of 2.6 [Table 1].

\subsection{Enzyme Activity}

On the basis of screening, all positive isolates were grown in specific liquid media and enzyme activity was measured, respectively. Amylase activity of 22 isolates was observed in the range of $200.36 \pm 32.8$ to $2473.29 \pm 16.3 \mathrm{U} / \mathrm{ml}$; cellulase activity of 23 isolates, from $38.1 \pm 2.1$ to $574.63 \pm 27.8 \mathrm{U} / \mathrm{ml}$; and pectinase activity of 17 isolates, from $430 \pm 43.5$ to $672.6 \pm 22.3 \mathrm{U} / \mathrm{ml}$ while protease activity for 31 isolates, from $1.8 \pm 0.09$ to $34.95 \pm 0.15 \mathrm{U} / \mathrm{ml}$ [Table 2]. Out of total 47 isolates, 
Table 1: Exoenzymes production by endophytic bacterial isolates.

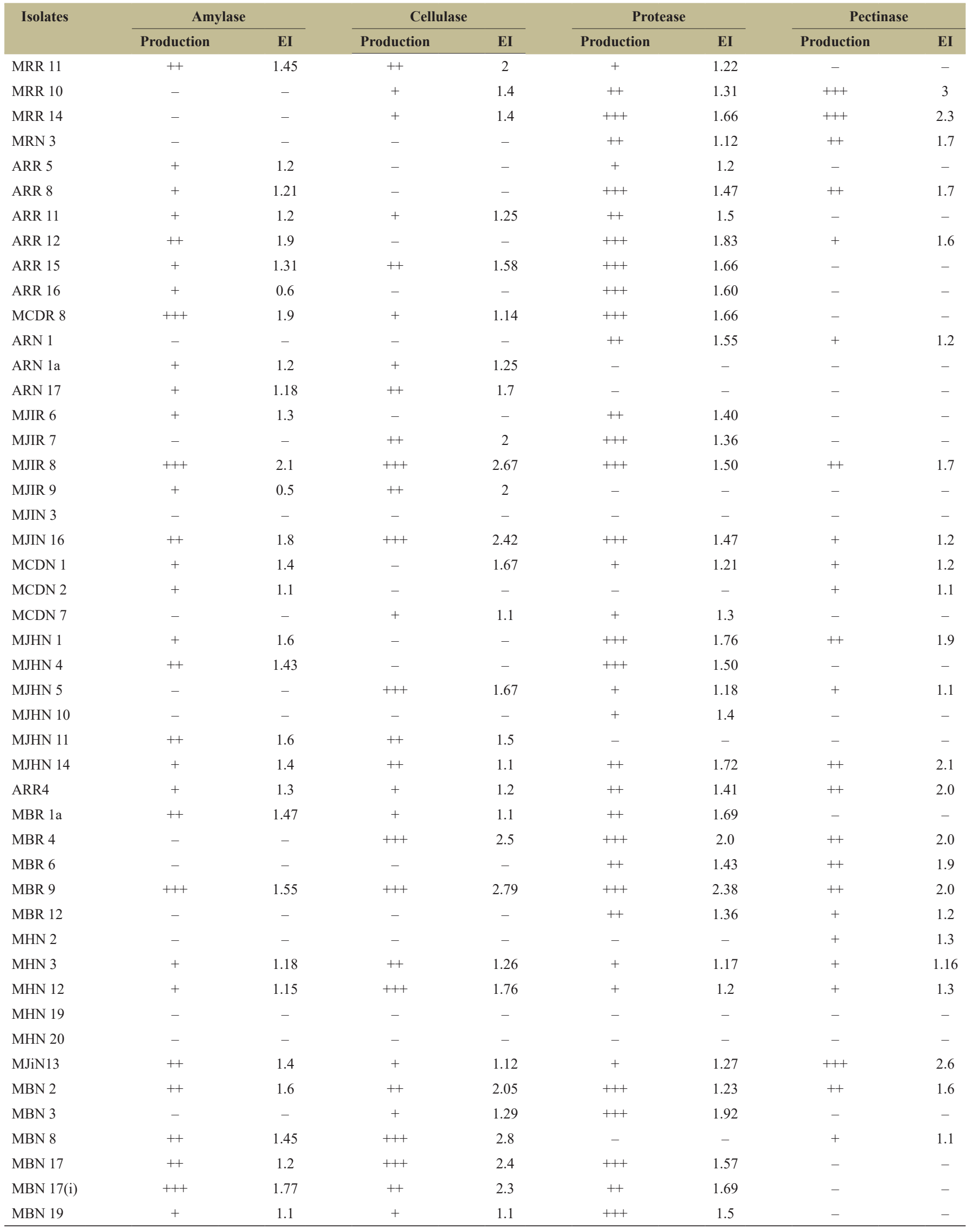

"EI" means enzymatic index, "-" means showed no production, "+" means showed low production, "++" means moderate production, "+++" means high production 
Table 2: Exoenzymatic activity of endophytic bacterial isolates from Vigna radiata and Cajanus cajan.

\begin{tabular}{|c|c|c|c|c|}
\hline Isolates & Amylase activity* & Cellulase activity * & Protease activity* & Pectinase activity* \\
\hline MRR 11 & $2473.29 \pm 16.3$ & - & $13.43 \pm 1.46$ & - \\
\hline MRR 10 & - & $97.14 \pm 3.6$ & $6.48 \pm 1.15$ & $605.1 \pm 24.1$ \\
\hline MRR 14 & - & $117.4 \pm 7.21$ & $6.7 \pm 2.35$ & $461.58 \pm 5.7$ \\
\hline MRN 3 & - & - & $19.44 \pm 2.1$ & $491.8 \pm 27.5$ \\
\hline ARR 8 & $904.89 \pm 24.4$ & - & $34.95 \pm 0.15$ & $430 \pm 43.5$ \\
\hline ARR 11 & $200.36 \pm 32.8$ & - & - & - \\
\hline ARR 12 & $305.93 \pm 25.1$ & - & $4.66 \pm 0.46$ & - \\
\hline ARR 15 & - & $38.1 \pm 2.1$ & - & - \\
\hline ARR 16 & - & - & $11 \pm 0.48$ & - \\
\hline MCDR 8 & $581.7 \pm 42.4$ & $473.71 \pm 25.7$ & $1.8 \pm 0.09$ & - \\
\hline ARN 17 & $452.43 \pm 52.9$ & - & - & - \\
\hline MJIR 6 & $1443.47 \pm 33.2$ & - & $18.65 \pm 1.8$ & - \\
\hline MJIR 7 & - & $111.22 \pm 2.1$ & $15.85 \pm 1.45$ & - \\
\hline MJIR 8 & $1247.42 \pm 67.9$ & $458.26 \pm 6.3$ & $19.44 \pm 2.1$ & $520.4 \pm 46.4$ \\
\hline MJIR 9 & $1049.21 \pm 24.7$ & $327.48 \pm 17.51$ & - & - \\
\hline MJIN 16 & $773.44 \pm 24.3$ & $359.74 \pm 10.82$ & $8.56 \pm 0.22$ & $521.4 \pm 3.3$ \\
\hline MCDN 1 & - & $503.35 \pm 4.12$ & $34.34 \pm 1.2$ & $657.7 \pm 3.4$ \\
\hline MJHN 1 & - & - & $28.86 \pm 0.26$ & $633.7 \pm 48.4$ \\
\hline MJHN 4 & $1139.7 \pm 20.8$ & - & $24.68 \pm 1.1$ & - \\
\hline MJHN 5 & - & $574.63 \pm 27.8$ & - & - \\
\hline MJHN 10 & - & - & $32.39 \pm 1.9$ & - \\
\hline MJHN 11 & $1021.2 \pm 64.9$ & $492.59 \pm 20.1$ & - & - \\
\hline MJHN 14 & $596.8 \pm 38.6$ & $293.15 \pm 11.9$ & $15.69 \pm 1.3$ & $510.1 \pm 13.7$ \\
\hline ARR4 & $533.2 \pm 18$ & $379.7 \pm 25.9$ & $21.1 \pm 0.59$ & $466.6 \pm 19.5$ \\
\hline MBR 1a & $1405.77 \pm 81.9$ & - & - & - \\
\hline MBR 4 & - & $423.25 \pm 30.9$ & $18.9 \pm 0.71$ & $672.6 \pm 22.3$ \\
\hline MBR 6 & - & - & $24.58 \pm 0.76$ & $597.1 \pm 10.5$ \\
\hline MBR 9 & $598.9 \pm 35.7$ & $484.01 \pm 13.39$ & $10.94 \pm 1.5$ & $621.1 \pm 21$ \\
\hline MHN 3 & $441.66 \pm 3.7$ & $13.04 \pm 2.6$ & $11.8 \pm 0.6$ & $503.23 \pm 29.3$ \\
\hline MHN 12 & $482.6 \pm 51.8$ & $398.5 \pm 3.1$ & $16.19 \pm 1.12$ & $468.9 \pm 31.5$ \\
\hline MHN 20 & - & - & $27.59 \pm 0.22$ & - \\
\hline MJiN13 & $404 \pm 19.4$ & $17.51 \pm 8.23$ & $15.8 \pm 0.34$ & $504.4 \pm 65.5$ \\
\hline MBN 2 & $1677.23 \pm 16.2$ & $188.8 \pm 21.1$ & $13.9 \pm 1.8$ & $598.2 \pm 5.2$ \\
\hline MBN 3 & - & - & $25.05 \pm 0.64$ & - \\
\hline MBN 8 & $1496.26 \pm 34.04$ & $461.35 \pm 19.57$ & $26.42 \pm 1.4$ & - \\
\hline MBN 17 & - & $453.8 \pm 26.26$ & $25.9 \pm 3.9$ & - \\
\hline MBN 17(i) & $1477.9 \pm 19.5$ & $485 \pm 8.23$ & $29.35 \pm 2.4$ & - \\
\hline MBN 19 & - & $64.9 \pm 1.03$ & $16.4 \pm 0.23$ & - \\
\hline
\end{tabular}

*activity measured in $\mathrm{U} / \mathrm{ml}$

29 isolates exhibited multiple (two or more) enzyme activities while ten isolates showed activity for only one enzyme. Nine isolates, namely, MJiR8, MJiN16, MJiN13, MJhN14, ARR4, MBR9, MHN3, MBN2, and MHN12 were found to produce all the four enzymes and showed significant enzyme activity as shown in Table 2. Recently, bioactive compounds and enzymes from microorganisms are attaining more attention as these are more active and stable than the enzymes sourced from animals and plants [34]. Production of hydrolytic exoenzymes by endophytic bacteria is important for their colonization in plant roots [36]. Variation in enzyme production by different isolates is probably due to their colonization capability [37]. The isolates with no hydrolytic enzyme production ability might be using some other strategy for penetrating the plant tissue. In another study, bacteria lacking gene for plant cell wall degradation is also reported as a successful endophyte which confirms the existence of two or more strategies for entrance of endophytic bacteria [38].

\subsection{Molecular Analysis and Identification}

Nine isolates producing all the four hydrolytic enzymes were selected for identification using 16S rDNA. On the basis of ARDRA profiling, 
five isolates ARR4, MBR9, MHN3, MJiN13, and MHN12 showed distinct restriction pattern. The amplified 16S rDNA products of these isolates were sequenced and BLAST analysis revealed their identity towards Bacillus megaterium NAP8 (MH744747), Bacillus subtilis NMP1 (MH744750), Bacillus cereus NMP2 (MH744751), Bacillus panacihumi NMP3 (MH744752), and Bacillus licheniformis (MG273753) [Table 3]. The sequences were submitted to GenBank and phylogenetic tree of closest related sequences obtained from NCBI was constructed using Neighbor-Joining method with 1000 bootstrap values [Figure 3]. The isolates which possessed all the four enzymes with significant enzyme activities belonged to Bacillus or its derived genera, the most abundant bacterial genera especially of the soil habitat. A variety of exoenzymes, namely, cellulases, proteases, pectinases, amylases, and lipases have been produced by genus Bacillus with significant enzyme activity due to its stability at varying $\mathrm{pH}$ and high temperature [11,39]. Several species of Bacillus genera, namely, B. megaterium, Bacillus cereus, B. mojavensis, B. sterothermophilus, and $B$. subtilis have been involved in protease production and used as the source of commercially available proteolytic enzymes [40,41]. Cellulase production with strong enzymatic activity has been reported in many Bacillus sp. including B. pumilis, B. cereus, B. licheniformis, etc. $[11,42]$. Pectinase production is an important aspect of endophytic bacteria for hydrolyzing pectin of middle lamella and spreading intercellularly in plant hosts [43]. Bacillus sp. is predominately known to produce alkaline pectinases which have importance in plant cell protoplast formation, retting and degumming of plant material and fruit waste treatment [44]. The extracellular amylase production by Bacillus sp., B. megaterium, B. licheniformis, and B. pumilis has also been reported in the previous studies [18,45]. Members of Bacillus sp. are considered as the important source of amylase production [46].

\subsection{Plant growth promoting traits}

The five isolates were able to produce ammonia as well as IAA $(11.83 \pm 0.54$ to $35.83 \pm 2.2 \mu \mathrm{g} / \mathrm{ml})$. All were producing HCN except MHN3; three isolates named MHN12, MJiN13, MHN3 were producing organic acid while isolate MBR9, MHN3, and MHN12 were producing siderophore. Only two isolates ARR4 and MBR9 were able to solubilize phosphate (Table 4). Endophytic bacteria are mostly recognized as potential plant growth promoters having various mechanisms to improve the plant growth [47]. Along with multiple enzyme production ability, these isolates also possessed four or more PGP traits. Endophytic bacteria influence the growth of plants directly by producing phytohormones, by solubilizing phosphate or fixing atmospheric nitrogen, and indirectly through producing secondary metabolites such as antibiotics, cyanide, and siderophores to inhibit pathogenic microorganisms. The endophytic actinobacteria associated with plant tissues are capable of promoting plant growth by making nutrients/substrates (e.g., phosphorous,

Table 3: Analysis of 16S rDNA gene sequences.

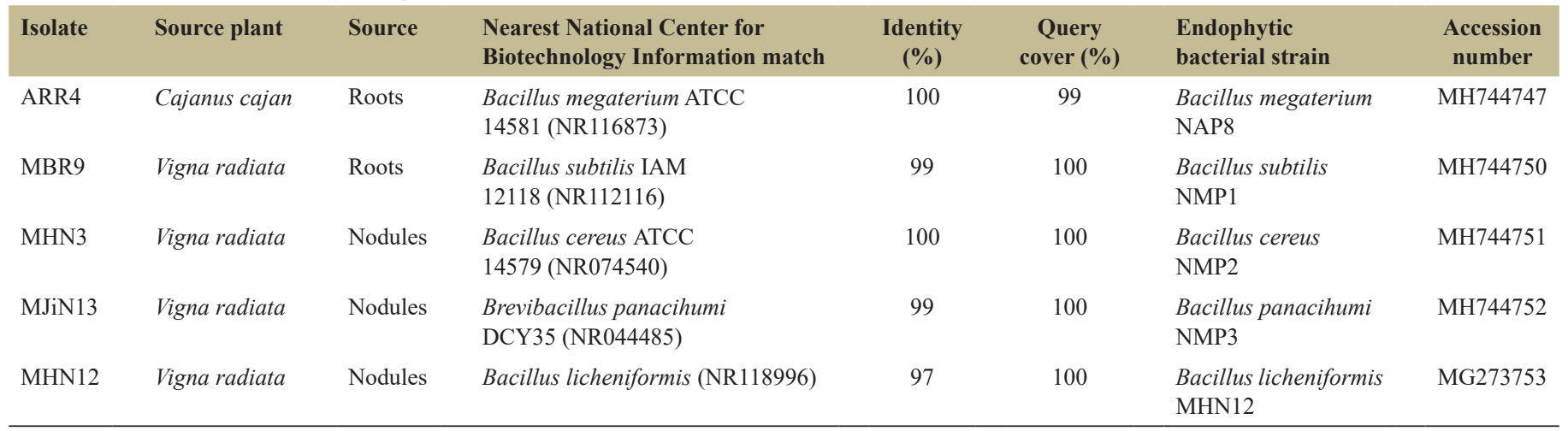

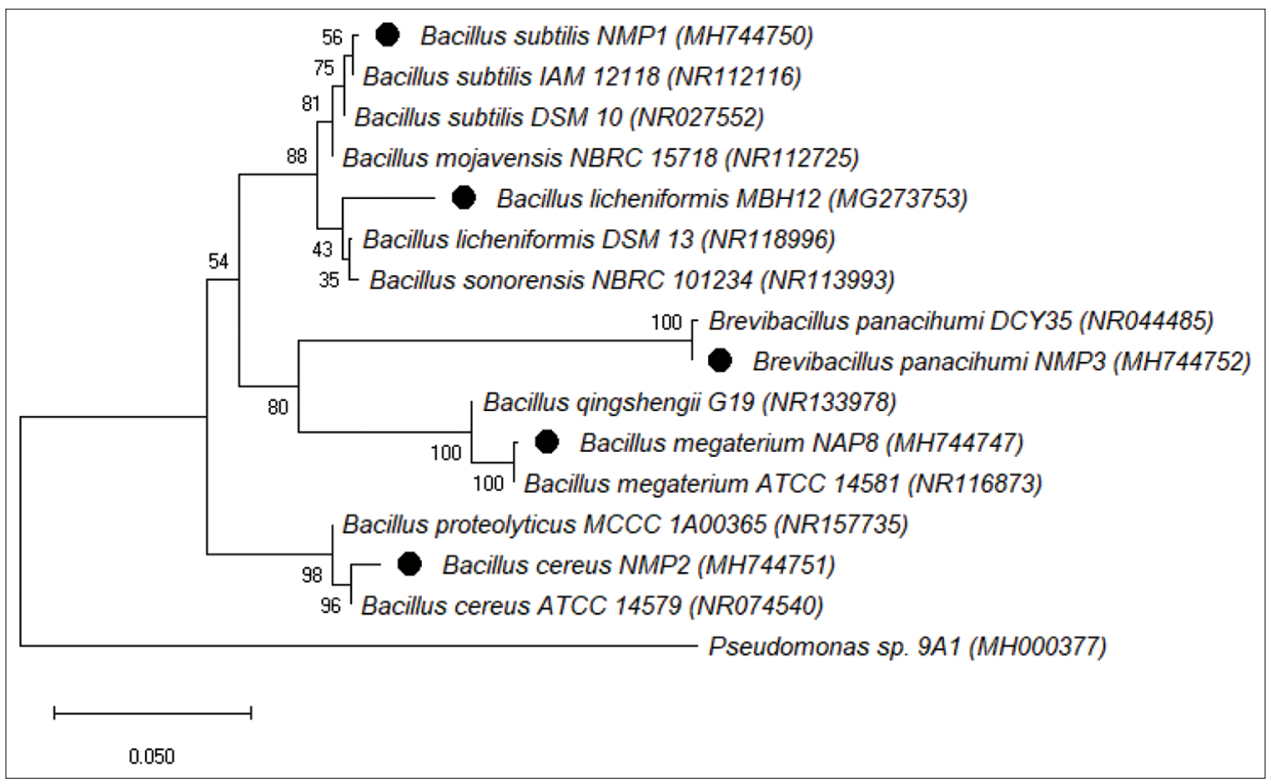

Figure 3: Phylogenetic tree based on 16S rRNA gene sequences of isolates with closest related sequences obtained from National Center for Biotechnology Information. 
Table 4: Plant growth promoting traits of selected endophytic bacterial isolates.

\begin{tabular}{lcccccc} 
Isolate & $\begin{array}{c}\text { Ammonia } \\
\text { production }\end{array}$ & $\begin{array}{c}\text { Organic acid } \\
\text { production }\end{array}$ & $\begin{array}{c}\text { Hydrogen cyanide } \\
\text { production }\end{array}$ & $\begin{array}{c}\text { IAA production } \\
(\mu \mathrm{g} / \mathrm{ml})\end{array}$ & $\begin{array}{c}\text { Phosphate } \\
\text { solubilization }\end{array}$ & $\begin{array}{c}\text { Siderophore } \\
\text { production }\end{array}$ \\
ARR4 & +++ & - & + & + & $24.9 \pm 0.51$ & ++ \\
MBR9 & +++ & - & - & $11.83 \pm 0.32$ & + & + \\
MHN3 & ++ & +++ & +++ & $35.83 \pm 2.2$ & - & - \\
MJiN13 & +++ & +++ & ++ & $27 \pm 0.7$ & - & - \\
MHN12 & ++ & +++ & ++ & + & + \\
\hline
\end{tabular}

IAA values are mean of three replicates \pm SD. "-" means showed no production, "+" means showed low production, "++" means moderate production, "+++" means high production

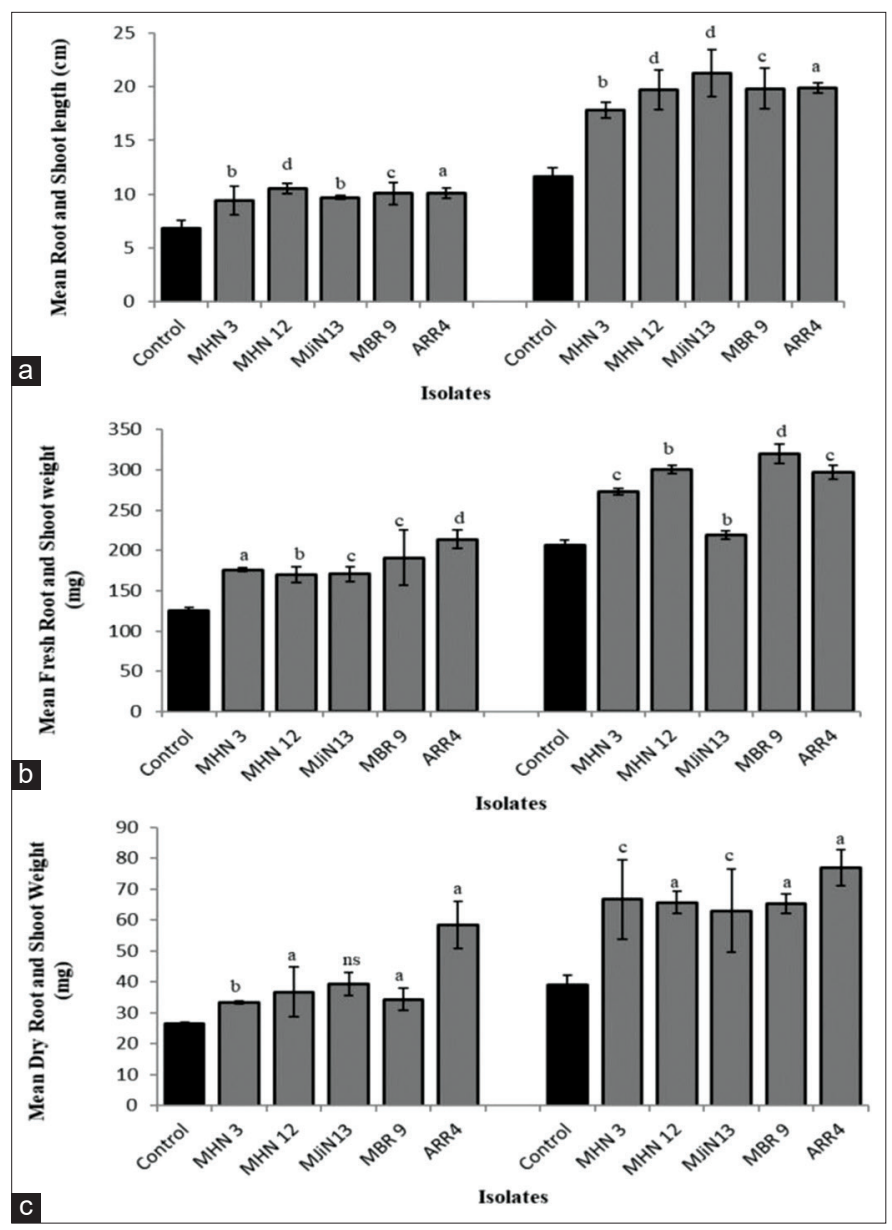

Figure 4: Effect of endophytic bacterial isolates on various growth parameters of Vigna radiata plants after 60 days of sowing (a) root and shoot length (b) fresh root and shoot weight (c) dry root and shoot weight. Values are presented as mean $\pm \mathrm{SD}$ $(n=4-6)$. Significantly different values $(P \leq 0.05)$ are marked by different letters (a-d). "ns" represents $P>0.05$, "d" represents $P \leq 0.05$; "c" represents $P \leq 0.01$; "b" represents $P \leq 0.001$; "a" represents $P \leq 0.0001$.

nitrogen, and iron) accessible to the host plant, producing various plant hormones and protection from phytopathogens [48].

\subsection{Pot Experiment}

The $V$. radiata seedlings bacterized with the five selected isolates (MHN3, MHN12, MJiN13, MBR9, and ARR4) significantly enhanced all the parameters including the root (up to 1.5 folds) and shoot (up to 1.8 folds) lengths, fresh root (up to 1.7 folds), shoot weights (up to 1.6 folds), dry root (up to 2.2 folds), and shoot (up to 2.0 folds) weights as compared with the control plants [Figure 4]. The statistical data showed that the inoculation with isolate ARR4 (Bacillus megaterium NAP8) resulted in significant increase in all the parameters $(P<0.05)$. None of the isolate resulted in nodulation in plant roots upon inoculation indicating nonrhizobial behavior. The PGP ability of these endophytes was also reflected in pot experiment performed, resulting in significant increase in all the parameters of plant growth as compared to uninoculated control. The results were in agreement with various previous reports of endophytic bacteria $[49,50]$. The hydrolytic enzymes produced by endophytic bacteria have also been found able to degrade cell wall of various pathogens and thus reported to possess the biocontrol activity [51]. Therefore, the endophytic bacteria with PGP as well as hydrolytic enzymes producing abilities are excellent alternative to chemical fertilizers and pesticides [52]. All the four enzymes simultaneously produced by one or more endophytic bacteria might have better agronomic and industrial applicability than that producing single enzyme activity.

\section{CONCLUSION}

Leguminous crops provide an exclusive niche harboring diverse group of microorganisms including endophytic bacteria. The present study explored the endophytic bacteria from $V$. radiata and C. cajan for their economic and ecological roles in sustainable agriculture and industrial productions. On the basis of hydrolytic enzymes production and PGP traits, it can be assessed that these endophytic bacteria lyse the cell wall, loosen plant cell contacts, and enter inside the plant tissue. The bacteria multiply there and facilitate the close association with the host plant providing better yield and reduced application of agro-chemicals. Moreover, these highly efficient strains with multiple enzyme production can be harnessed as potentially favorable candidates for use in industrial field.

\section{CONFLICTS OF INTEREST}

The author declares that there is no conflict of interest.

\section{ACKNOWLEDGEMENT}

This research work was supported by financial grant (SB/YS/LS273/2013) sanctioned by Department of Science and Technology, Government of India, New Delhi, India. NB received university research scholarship. Authors are also thankful to the Department of Microbiology, MD University, Rohtak, for providing infrastructure support.

\section{REFERENCES}

1. Lodewyckx C, Vangronsveld J, Porteous F, Moore ER, Taghavi S, Mezgeay $\mathrm{M}$, et al. Endophytic bacteria and their potential applications. Crit Rev Plant Sci 2002;21:583-606.

2. Ryan RP, Germaine K, Franks A, Ryan DJ, Dowling DN. Bacterial endophytes: Recent developments and applications FEMS Microbiol 
Lett 2008;278:1-9.

3. Glick BR. Plant growth-promoting bacteria: Mechanisms and applications. Scientifica 2012;2012:963401.

4. Ausubel FM, Brent R, Kingston RE, Moore DD, Seidman JG, Smith JA, et al. Short Protocols in Molecular Biology. Ch. 2.4. New York: John Wiley and Sons; 1995.

5. Maheshwari R, Bhutani N, Suneja P. Isolation and characterization of ACC deaminase producing endophytic Bacillus mojavensis PRN2 from Pisum sativum. Iran J Biotechnol 2020;18:11-20.

6. Sørensen J, Sessitsch A. In: van Elsas JD, Trevors JT, Jansson JK, editors. Plant-Associated Bacteria-lifestyle and Molecular Interactions. Boca Raton, Florida: CRC Press; 2007. p. 211-36.

7. Al-Mallah MK, Davey MR, Cocking EC. Enzymatic treatment of clover root hairs removes a barrier to Rhizobium-host specificity. Nat Biotechnol 1987;5:1319.

8. Sharma A, Singh P, Sarmah BK, Nandi SP. Isolation of cellulosedegrading endophyte from Capsicum chinense and determination of its cellulolytic potential. Biointerface Res Appl Chem 2020;10:6964-73.

9. Jalgaonwala RE, Mahajan RT. Isolation and characterization of endophytic bacteria from roots of Pongamia glabra Vent. Int J Pharm Biol Sci 2011;1:280-7.

10. Sethi S, Datta A, Gupta BL, Gupta S. Optimization of cellulase production from bacteria isolated from soil. ISRN Biotechnol 2013;2013:985685.

11. Casstro RA, Quecine MC, Lacava PT, Batista BD, Luvizotto DM, Marcon J. Isolation and enzyme bioprospection of endophytic bacteria associated with plants of Brazilian mangrove ecosystem. Springerplus 2014;3:382.

12. de Souza PM, de Oliveira Magalhães P. Application of microbial $\alpha$-amylase in industry A review. Braz J Microbiol 2010;41:850-61.

13. Khan MA, Ahmad N, Zafar AU, Nasir IA, Qadir MA. Isolation and screening of alkaline protease producing bacteria and physio-chemical characterization of the enzyme. Afr J Biotechnol 2011;10:6203-12.

14. Kashyap DR, Vohra PK, Chopra S, Tewari R. Applications of pectinases in commercial sector: A review. Biosour Technol 2001;77:215-27.

15. Mercado-Blanco J, Lugtenberg B. Biotechnological applications of bacterial endophytes. Curr Biotechnol 2014;3:60-75.

16. Bhutani N, Maheshwari R, Negi M, Suneja P. Optimization of IAA production by endophytic Bacillus spp. from Vigna radiata for their potential use as plant growth promoters. Israel J Plant Sci 2018;65:83-96.

17. Maheshwari R, Bhutani N, Bhardwaj A, Suneja P. Functional diversity of cultivable endophytes from Cicer arietinum and Pisum sativum: Bioprospecting their plant growth potential. Biocatal Agric Biotechnol 2019a;20:101229.

18. Hankin L, Anagnostakis SL. The use of solid media for detection of enzyme production by fungi. Mycologia 1975;67:597-607.

19. El-Deeb B, Bazaid S, Gherbawy Y, Elhariry H Characterization of endophytic bacteria associated with rose plant (Rosa damascenatrigintipeta) during flowering stage and their plant growth promoting traits. J Plant Interact 2012;7:248-53.

20. Zaghloul RA, Abou-Aly HE, Tewfike TA, Ashry NM. Isolation and characterization of endophytic bacteria isolated from legumes and non-legumes plants in Egypt. J Pure Appl Microbiol 2016;10:277-90.

21. Mateos PF, Jimenez-Zurdo JI, Chen J, Squartini AS, Haack SK. Cell-associated pectinolytic and cellulolytic enzymes in Rhizobium leguminosarum biovar trifolii. Appl Environ Microbiol 1992;58:1816-22.

22. Kembhavi AA, Kulkarni A, Pant A. Salt-tolerant and thermostable alkaline protease from Bacillus subtiltis NCIM No. 64. Appl Biochem Biotechnol 1993;38:83-92.

23. Weisburg WG, Barns SM, Pelletier DA, Lane DJ. 16S ribosomal
DNA amplification for phylogenetic study. J Bacteriol 1991;173:697-703.

24. Suneja P, Piplani S, Dahiya P, Dudeja SS. Molecular characterization of mesorhizobia forming nodules on reverted non nodulating selection and normal cultivar of chickpea. J Agr Sci Tech 2016;18:763-73.

25. Rohlf F. NTSYS-pc-Numerical Taxonomy and Multivariate Analysis System. New York: Applied Biostatistics Inc.; 1988.

26. Kumar S, Stecher G, Li M, Knyaz C, Tamura K. MEGA X: Molecular evolutionary genetics analysis across computing platforms. Mol Biol Evol 2018;35:1547-9.

27. Cappucino JG, Sherman N. Microbiology: A Laboratory Manual. New York: The Benjamin/Cummings Publ. Co. Inc.; 1992.

28. Lorck H. Production of hydrocyanic acid by bacteria. Physiol Plant 1948;1:142-6.

29. Schwyn B, Neilands JB. Universal chemical assay for the detection and determination of siderophores. Anal Biochem 1987;160:47-56.

30. Pikovskaya RI. Mobilization of phosphorus in soil in connection with vital activity of some microbial species. Mikrobiologiya 1948; 17:362-70.

31. Tang YW, Bonner J. The enzymatic inactivation of indole acetic acid. II. The physiology of the enzyme. Am J Bot 1948;35:570-8.

32. Madan PS, Dahiya P. Diversity and effectivity of mesorhizobia nodulating reverted non nodulating lines of chickpea in comparison to the normal cultivar. Plant Arch 2013;13:929-35.

33. Sánchez-Porro C, Martin S, Mellado E, Ventosa, A. Diversity of moderately halophilic bacteria producing extracellular hydrolytic enzymes. J Appl Microbiol 2003;94:295-300.

34. Vijayalakshmi R, Kairunnisa K, Sivvaswamy SN, Dharan SS, Natarajan S. Enzyme production and antimicrobial activity of endophytic bacteria isolated from medicinal plants. Indian J Sci Technol 2016;9:1-8.

35. Carrim AJI, Barbosa EC, Vieira JD. Enzymatic activity of endophytic bacterial isolates of Jacaranda decurrens Cham. (Carobinha-docampo). Braz Arch Biol Technol 2006;49:353-59.

36. Sakiyama CC, Paula EM, Pereira PC, Borges AC, Silva DO. Characterization of pectin lyase produced by an endophytic strain isolated from coffee cherries. Lett Appl Microbiol 2008;33:117-21.

37. Verma SC, Ladha JK, Tripathi AK. Evaluation of plant growth promoting and colonization ability of endophytic diazotrophs from deep water rice. J Biotechnol 2001;91:127-41.

38. Pedrosa FO, Monteiro RA, Wassem R, Cruz LM, Ayub RA. Genome of Herba spirillumseropedicae strain SmR1, a specialized diazotrophic endophyte of tropical grasses. PLoS Genet 2011;7:e1002064.

39. Yang JK, Shih IL, Tzeng YM, Wang SL. Production and purification of protease from Bacillus subtilis that can deproteinize crustacean wastes. Enzyme Microb Technol 2000;26:406-13.

40. Ferreira CM, Soares HM, Soares EV. Promising bacterial genera for agricultural practices: An insight on plant growth-promoting properties and microbial safety aspects. Sci Total Environ 2019;682:779-99.

41. Shumi W, Hossain MT, Anwar MN. Proteolytic activity of a bacterial isolate Bacillus fastidiosus den Dooren de Jong. J Biol Sci 2004;4:370-4.

42. Tabao NC, Moasalud RG. Characterization and identification of high cellulose-producing bacterial strains from Philippine mangroves. Philipp J Syst Biol 2010;4:13-20.

43. Abdollahzadeh R, Pazhang M, Najavand S, FallahzadehMamaghani V, Amani-Ghadim AR. Screening of pectinase-producing bacteria from farmlands and optimization of enzyme production from selected strain by RSM. Folia Microbiol 2020;65:705-19.

44. Rivera MH, Lopez-Munguia A, Soberon X, Saab-Rincom G. Alphaamylase from Bacillus licheniformis mutants near to the catalytic site: Effects on hydrolytic and transglycosylation activity. Protein Eng 2003;16:505-14. 
45. Pandey A, Nigam P, Soccol CR, Soccol VT, Singh D, Mohan R. Advances in microbial amylases. Biotechnol Appl Biochem 2000;31:135-52.

46. Dudeja SS, Giri R, Saini R, Suneja-Madan P, Kothe E. Interaction of endophytic microbes with legumes. J Basic Microbiol 2012;52: 248-60.

47. Maheshwari R, Bhutani, N, Suneja P. Screening and characterization of siderophore producing endophytic bacteria from Cicer arietinum and Pisum sativum plants. J Appl Biol Biotechnol 2019b;7:7-14.

48. Amaresan N, Kumar K, Madhuri K, Usharani GK. Isolation and characterization of salt tolerant plant growth promoting rhizobacteria from plants grown in Tsunami affected regions of Andaman and Nicobar Islands. Geomicrobiol J 2016;33:942-7.

49. Walitang DI, Kim K, Madhaiyan M, Kim YK, Kang Y, Sa T. Characterizing endophytic competence and plant growth promotion of bacterial endophytes inhabiting the seed endosphere of Rice. BMC Microbiol 2017;17:1-13.

50. Zhang Y, Kang X, Liu H, Liu Y, Li Y. Endophytes isolated from ginger rhizome exhibit growth promoting potential for Zea mays. Arch Agric Soil Sci 2018;64:1302-14.

51. Reinhold-Hurek B, Hurek T, Gillis M, Hoste B, Vancanneyt M, Kersters $\mathrm{K}$, et al. Azoarcus gen. Nov., nitrogen-fixing proteobacteria associated with roots of Kallar grass (Leptochloa fusca (L.) Kunth), and description of two species, Azoarcus indigens sp. Nov. and Azoarcus communis sp. Nov. Int J Syst Evol Microbiol 1993;43:574-84.

52. Passari AK, Mishra VK, Gupta VK, Yadav MK, Saikia R, Singh BP. In vitro and in vivo plant growth promoting activities and DNA fingerprinting of antagonistic endophytic actinomycetes associates with medicinal plants. PLoS One 2015;10:e0139468.

\section{How to cite this article:}

Bhutani N, Maheshwari R, Kumar P, Dahiya R, Suneja P. Bioprospecting for extracellular enzymes from endophytic bacteria isolated from Vigna radiata and Cajanus cajan. J App Biol Biotech. 2021;9(3):26-34. DOI: $10.7324 / J A B B .2021 .9304$ 